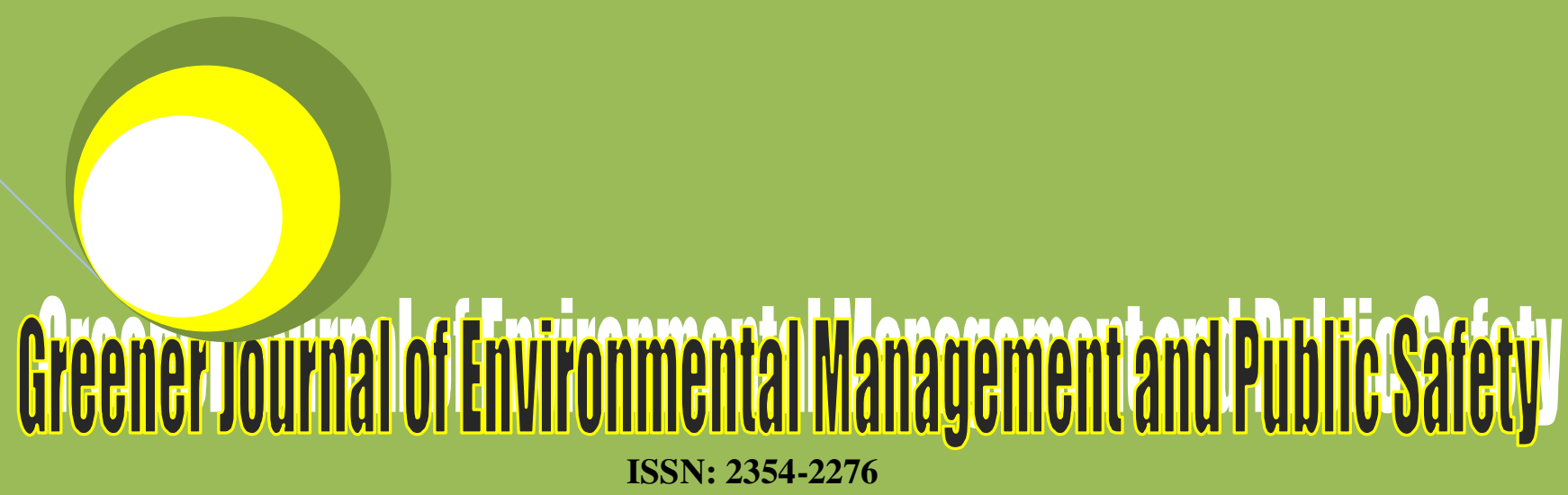

Submission Date: 27/02/014

Accepted: 09/07/014

Published: 11/07/014

Chanceline Bahati Mutalemba

Etienne Mugaruka Mashimango Godefroid Kubisibwa Mulengera Soleil Habamungu Shalukoma 


\title{
Conservation Strategy of Kahuzi-Biega National Park (KBNP) by the use of Biogas among the Surrounding Population
}

\section{Chanceline Bahati Mutalemba ${ }^{*}$, Etienne Mugaruka Mashimango ${ }^{2}$, Godefroid Kubisibwa Mulengera ${ }^{1}$ and Soleil Habamungu Shalukoma ${ }^{3}$}

\author{
${ }^{1}$ Researcher in Natural Sciences Research Center (CRSN-Lwiro in DRCongo), Environment Department. \\ ${ }^{2}$ Assistant in CEPROMAD University (Bukavu DRCongo). \\ ${ }^{3}$ Researcher in Natural Sciences Research Center (CRSN-Lwiro in DRCongo), Biology Department.
}

*Corresponding Author’s Email: bahatimutalemba@yahoo.fr; mugarukae@yahoo.fr

\begin{abstract}
This article studied the Kahuzi-Biega National park conservation strategy, by using Biogas technics among the neighboring population. The global objective was to predict villages possibility to be involved in the conservation of the KBNP by using biogas technics. We used data from 100 households in two surrounding villages of the park to produce theorical propositions. We used the analytic method as well as the observation technic. The conservation practices engaged few households as the results showed. The consumption of each household is $10 \mathrm{~kg}$ of wood and charcoal per day; this brought that consumption to 3.36 tons per year for one household. $6.5 \%$ of household accepted to plant trees in their fields among other cultures and $93.5 \%$ were against. The people used manure and the fertilizer coming from the digester in their fields; it contributed to grow up the cattle farming and fought against poaching. Therefore, one installed digester of $4 \mathrm{~m}^{3}$ for a household saved $20 \mathrm{~kg}$ of embers and wood per day, and more than 20.3tons by installing 1.000 digesters. Once this technology was used, the intensity of Kahuzi-Biega Park destruction reduced appreciably.
\end{abstract}

Key words: Conservation, Strategy, Kahuzi-Biega, Biogas.

NON-STANDARD ABBREVIATIONS: KBNP: Kahuzi-Biega National Park; NPB-BF: National program of biodigester for Bourkina-Faso.

\section{INTRODUCTION}

In this time when the entire world is preoccupied with the matter of global warming, the disappearance of rare natural resources and unrenewable, it is better to be interested in the Congolese natural heritage which is disappearing. In 1824, Joseph FOURIER, French physicist, nicknamed "greenhouse» the phenomenon demonstrated by Horace Bénédict de SAUSSURE in the end of 18th century saying: the temperature on the earth is grown up by the atmosphere which targets or traps a part of infrared radiation given off with the earth. From 1896, ARRHENIUS was announcing that in burning the coal, people had to warm up the planet via a greenhouse reinforced, and was therefore the first to highlight the risk of global warming. He indicated already with a great perceptiveness that the split concentration of carbon dioxide in the atmosphere had to lead to the temperature increase from $4^{\circ} \mathrm{C}$ to $6^{\circ} \mathrm{C}$. In 1979 , the American national academy of sciences spears the first rigorous study on the global warming. The Charney committee which was in charge has concluded already that " if the emissions of carbon dioxide continue to increase, the study group hasn't any reason to think those changes will be negligible. Therefore, it requires urgent and durable answers to that phenomenon (www.notreplanete.info). Biogas is appropriated to preserve the environment and our parks. Biogas typically refers to a gas produced by the breakdown of organic matter in the absence of oxygen (Bertrand De La Farge, 1995). It is a renewable source, like solar wind energy. Furthermore, biogas can be produced from regionally available raw materials such as recycled waste and is environmentally friendly (Berger S. and Couturier C., 2008). Biogas is produced by anaerobic digestion with anaerobic bacteria or fermentation of biodegradable such as manure, sewage, municipal waste, green waste, plant material, and crops (National Non-Food Crops Centre, 2011). It is primarily methane $\left(\mathrm{ch}_{4}\right)$ and carbon dioxide $\left(\mathrm{CO}_{2}\right)$ and may have small amounts of hydrogen sulphide (H2S), moisture and siloxanes. The gases methane, hydrogen and carbon monoxide ( $\mathrm{CO}$ ) can be combusted or 
oxidized with oxygen. This energy release allows biogas to be used as a fuel; it can be used for any heating purpose such as cooking. It can also be used in a gas engine to convert the energy in the gas into electricity and heat (Clarke-energy.com). Biogas can be compressed the same way natural gas is compressed, and used to power motors vehicles. In the Uk, for example, biogas is estimated to have the potential to replace around $17 \%$ of vehicle fuel (Claverton Energy conference, 2009). It qualifies for renewable energy subsidies in some part of the world. Biogas can be cleaned and upgraded to natural gas standards when it becomes biomethane (State Energy conservation Office, 2009). There are two key processes: Mesophilic and thermophilic (NPB-BF, 2005). Landfill gas is produced by wet organic waste decomposing under anaerobic conditions in a landfill (Burdekin, 2003). As produced, biogas contains water vapor (Champiat D. et al. 1994). The fractional volume of water vapor is a function of biogas temperature; correction of measured gas volume for water vapor content and thermal expansion is easily done via simple mathematics (13) which yields the standardized volume of dry biogas. In some cases, biogas contains siloxanes (www.clarke-energy.com).

Before all environmental difficulties, we are called to put two key questions:

How can the use of biogas in the vicinity of the (K.B.N.P) contribute to his conservation? How can biogas partake in the promotion of agriculture and cattle farming of the resident around the Park in order to dissuade them from resorting often to poaching and cutting wood on a grand scale?

The objective of this study is to encourage the power which has the management of the parks in his attribution in general and the management of the KBNP in particular to appropriate and support the result of this study in order to bring the populations surrounding the KBNP to the use of all the aspects of domestic biogas technology.

\section{MATERIALS AND METHODS}

Concerning the methods, we used the analytic method, the documentary method, and the direct observation and the interview technics. The inquiry questionnaire has allowed us to harvest data on the situation around the Park. From historical and actual data, we made a sort and kept those which are relevant and relative to the object of our study. The materials used are the digester, the organic waste, the gaziometer, the gas bulb, the gas stove, the hose, the pipe, etc.

\section{As studied area}

KBNP is located in east of the Democratic Republic of Congo, belonging to three provinces: the South/Kivu, the North/Kivu and the Maniema (figure1). It is surrounded by the administrative territories of Kabare, Walungu, Kalehe, Shabunda, Punia and Walikale. Geographically, it is located at $1^{\circ} 36^{\prime}-2^{\circ} 27^{\prime}$ south latitude and $27^{\circ} 33^{\prime}-28^{\circ}$ 46 East longitudes (Fisher, 1995). Buy the arrangement n'81/Agriculture of 27/7/1937; the zoologic and forest reserve of Kahuzi-Biega was introduced by the Belgium colonial administration in order to regulate the natural resources exploitation in this part of the humid and tropical forest located in the mountainous Kivu. In 1970, this reserve, located in the high altitude (1200-3308m) has taken the National Park status with a view to integrate the protection of the biodiversity with a particular attention to plain gorilla of the East, Gorilla berengei graueri, a endemic kind in the forest of the east of DRCongo. It was enlarged by the order-law $N^{\circ} 75 / 238$ integrating a immense forest of the central basin passing from 60.000 to 600.000 hectors (Mugaruka, 2012). In 1975, it has been enlarged to the low altitude (600-1200m). In 1980, by the Congolese law $n^{\circ} 80 / 008$ of $18 / 7 / 1980$, the KBNP was registered on the list of the world heritage sites of UNESCO. Following a high human pressure, in 1996 it was declared world heritage site in danger (UNESCO, 1997). The inquired areas were mainly Bugorhe and Irhambi/Katana groupments, in Kabare territory with the aim of extending this study on all South-Kivu province. This part comes from Tshivanga station up to Kabamba in the North of Bukavu town. 


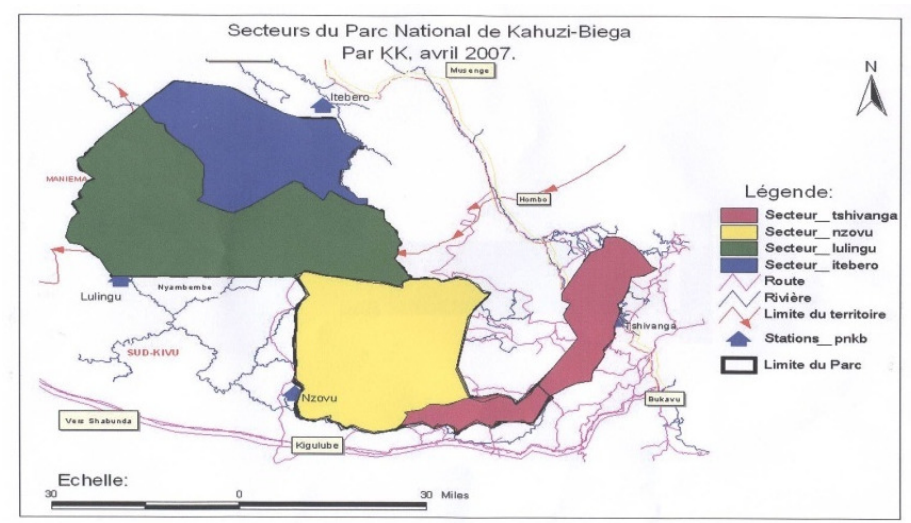

Figure 1: The KBNP map

Biogas plant is the name often given to an anaerobic digester that treats farm wastes or energy crops. It can be produced using anaerobic digesters. These plants can be fed with energy crops such as Maize silage or biodegradable wastes including sewage sludge and food waste. During the process a- air-tight tank transforms biomass waste into methane producing renewable energy that can be used for heating, electricity, and many other operations that use an internal combustion engine, such as GE jenbacher gas engines (State energy conservation Office, 2009).

We realize that the number of children in the household increases the quantity of firewoods used or the charcoals. In each household we have in average 7persons in which are 5 children and 2 parents. Each house household consumes in average 10,2 kg of firewood per day for those who use wood and 9,5kg of charcoal per day for those who use charcoals in cooking. According to our inquiry, each person uses in average 1,5kg of firewood, and in the household which uses charcoals each person consumes $1,2 \mathrm{~kg}$ per day. This deduces that $(10,2 \mathrm{~kg}+9,5 \mathrm{~kg}) / 2=9,85 \approx 9,9 \mathrm{Kg}$. This numeral would mean that each family uses almost $10 \mathrm{Kg}$ of firewood and charcoal put together per day among these populations surrounding the KBNP.

\section{RESULTS}

The daily need of firewood and charcoal for a middle family in the vicinity of KBNP was $10 \mathrm{~kg}$. This means that each household in that area has used $3.360 \mathrm{~kg}$ per year.

Table 1: Results after inquiry

\begin{tabular}{|l|l|l|l|l|}
\hline $\begin{array}{l}\text { Medium number } \\
\text { of children per } \\
\text { household }\end{array}$ & Parents & $\begin{array}{l}\text { Medium quantity } \\
\text { of firewood used } \\
\text { per day }(\mathrm{Kg})\end{array}$ & $\begin{array}{l}\text { Medium quantity } \\
\text { of charcoal used } \\
\text { per day }(\mathrm{Kg})\end{array}$ & $\begin{array}{l}\text { Medium quantity firewood } \\
\text { and charcoal used per day } \\
\text { and per household }(\mathrm{Kg})\end{array}$ \\
\hline 5 & 2 & 10,2 & 9,5 & 9,9 \\
\hline
\end{tabular}

Source: Our inquiry on ground.

Caption: the haversted data gave us after the average, 5 children per house hold inquiried, 2 parents, 10.2 firewood used per day by households which use only firewood, $9,5 \mathrm{~kg}$ charcoal used per day by households which use only charcoal, $9.9 \mathrm{~kg}$ is the average calculated by $10,2 \mathrm{~kg}$ and $9,5 \mathrm{~kg}$ therefore $\frac{10,2 \mathrm{~kg}+9,5 \mathrm{~kg}}{2}=9,85 \mathrm{~kg} \approx 9,9 \mathrm{Kg}$.

The digesters categories very often used in domestic digesters are: $4 \mathrm{~m}^{3}, 6 \mathrm{~m}^{3}, 8 \mathrm{~m}^{3}$ and $10 \mathrm{~m}^{3}$. This study was made by taking into account the use of the digester of $4 \mathrm{~m}^{3}$. This would mean that the digester can be accessible to all the social strata and the estimate can be easily paid by most of the households even the one which has a little income. We would say that this kind of digester doesn't require many cows to get waste or manure to work that digester; from 2 cows of ameliorated race or 3 ordinary cows. In that case $90 \%$ of combustibles replaced by the biogas is the firewood and $8 \%$ of combustibles replace is charcoal, the following quantity will be given back to the nature of KBNP for the numeral of $4 \mathrm{~m}^{3}$ digesters used: 
Table 2: Quantity of firewood and charcoal to return to the nature by the digesters of $4 \mathrm{~m}^{3}$

\begin{tabular}{|c|c|c|c|}
\hline $\begin{array}{l}\text { Number } \\
\text { installed } \\
\text { digesters }\end{array}$ & $\begin{array}{l}\text { Quantity of firewood } \\
\text { to replace }\end{array}$ & $\begin{array}{l}\text { Quantity of charcoal } \\
\text { to replace }\end{array}$ & $\begin{array}{l}\text { Quantity of firewood } \\
\text { and charcoal to return } \\
\text { per day }\end{array}$ \\
\hline 1 & $19.8 \mathrm{Kg}$ vs $3.6 \mathrm{~m}^{3}$ & $0.5 \mathrm{Kg}$ vs $0.32 \mathrm{~m}^{3}$ & $19.8 \mathrm{~kg}+0.5 \mathrm{~kg}=20.3 \mathrm{Kg}$ \\
\hline 10 & $198 \mathrm{Kg}$ vs $60 \mathrm{~m}^{3}$ & $5 \mathrm{Kg}$ contre $3.2 \mathrm{~m}^{3}$ & $198 \mathrm{Kg}+5 \mathrm{~kg}=203 \mathrm{~kg}$ \\
\hline 100 & $\begin{array}{l}\begin{array}{l}1980 \mathrm{~kg} \\
360 \mathrm{~m}^{3}\end{array} \text { or } 1.98 \mathrm{t} \text { vs } \\
\end{array}$ & $\begin{array}{llll}51.2 \mathrm{~kg} & \text { or } & 0.05 \mathrm{t} & \mathrm{vs} \\
32 \mathrm{~m}^{3} & & & \\
\end{array}$ & $1.98 \mathrm{t}+0.05 \mathrm{t}=2.03 \mathrm{t}$ \\
\hline 1000 & $\begin{array}{l}19.800 \mathrm{~kg} \text { or } 19.8 \mathrm{t} \text { vs } \\
3.600 \mathrm{~m}^{3} \text { of biogas }\end{array}$ & $\begin{array}{l}512 \mathrm{~kg} \text { or } 0.5 \mathrm{t} \text { vs } \\
320 \mathrm{~m}^{3} \text { of biogas }\end{array}$ & $19.8 t+0.5 t=20.3 t$ \\
\hline 10.000 & $\begin{array}{l}198.000 \mathrm{~kg} \text { or } 198 \mathrm{t} \text { vs } \\
36.000 \mathrm{~m}^{3}\end{array}$ & $\begin{array}{l}5.120 \mathrm{~kg} \text { or } 5.12 \mathrm{t} \text { vs } \\
3.200 \mathrm{~m}^{3}\end{array}$ & $198 t+5.12=203.12 t$ \\
\hline
\end{tabular}

Source : Our inquiry on ground

We realize that $19.8+0.5=20.3$ tons of firewoods and charcoals to return to the nature per day. If we divide 20.3 tons by 3.36 ton, we will have 6 . This numeral means that the installation of 1000 digesters of $4 \mathrm{~m}^{3}$ can return to the KBNP his heritage destroyed 6 years ago by one household located in his vicinity. 20.3 tons divided to $24 \mathrm{hours}$, gives us the number of tons replaced by the biogas digester of $4 \mathrm{~m} 3$ per hour, the numeral is 0.9 ton/hour after the installation of 1000 digesters.

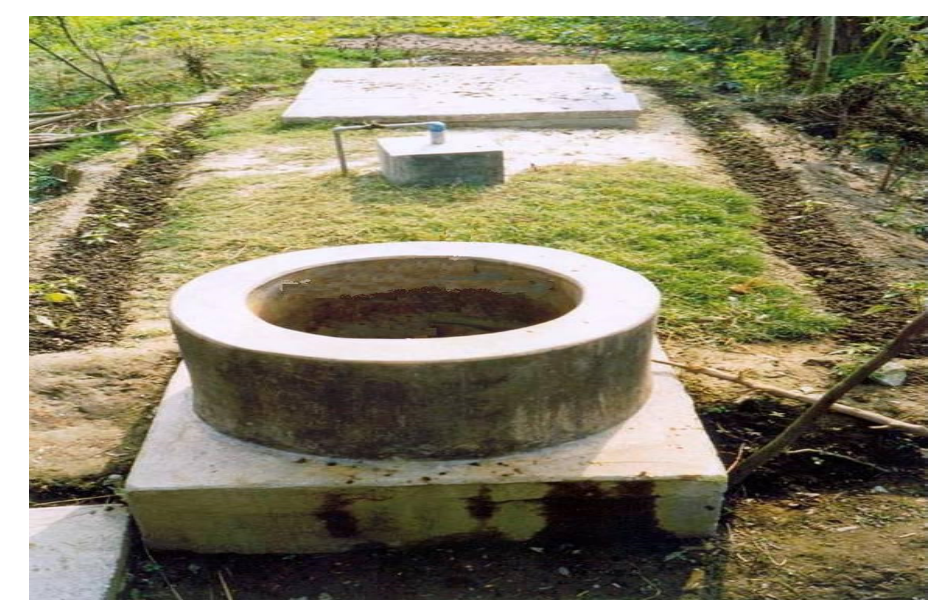

Figure 2: Domestic digester

Source: convent of Jesuites priests of Cyangugu/Rwanda.

Each biogas meter cube contains equivalent of 6Kilowatts hour of calorific energy (electrigaz.com). The Kilowatt hour is a measure unit of an energy by consumed by a device of 1000 Watts (1Kwh) of power during a duration of one hour. It is specially used to measure the electric energy, as well as generated (electric generator ...) and which is consumed (plate of cooking,...). But the definition of that unit is applied to all the domains (including the non-electric domains). For knowing the energy consumed by a device it should therefore multiply his power (in kilowatts) by his use duration (in hours). Example a device of 2500W (2.5kw) used at a maximum power during 2hours will consume $2.5 \mathrm{kw} \times 2 \mathrm{~h}=5 \mathrm{kwh}$ in all (annex 1 of the Brochure concerning the international system of Units, 1997).

Likewise, one meter cube of gas of France is equal to 11.06 kilowatt hours this means that $1 \mathrm{~m}^{3}=11.06 \mathrm{kwh}$ (Ch. couturier- solagro, 2009). One- meter cube of domestic biogas is equaled to a caloric value of $5.5 \mathrm{~kg}$ for firewood and $1.6 \mathrm{~kg}$ for embers or charcoal (Programme national de Biogaz du Burkina-Faso (NPBBF), 2005). It is important if among those people surrounding the park can be found 1,000 farmers who are ready to enhance the value of manure waste in building domestic biogas digesters of $4 \mathrm{~m}^{3}$ in their household. In this condition we can expect to a have satisfied result where charcoal and fire wood will be replaced by the use of gas stove in each household. 


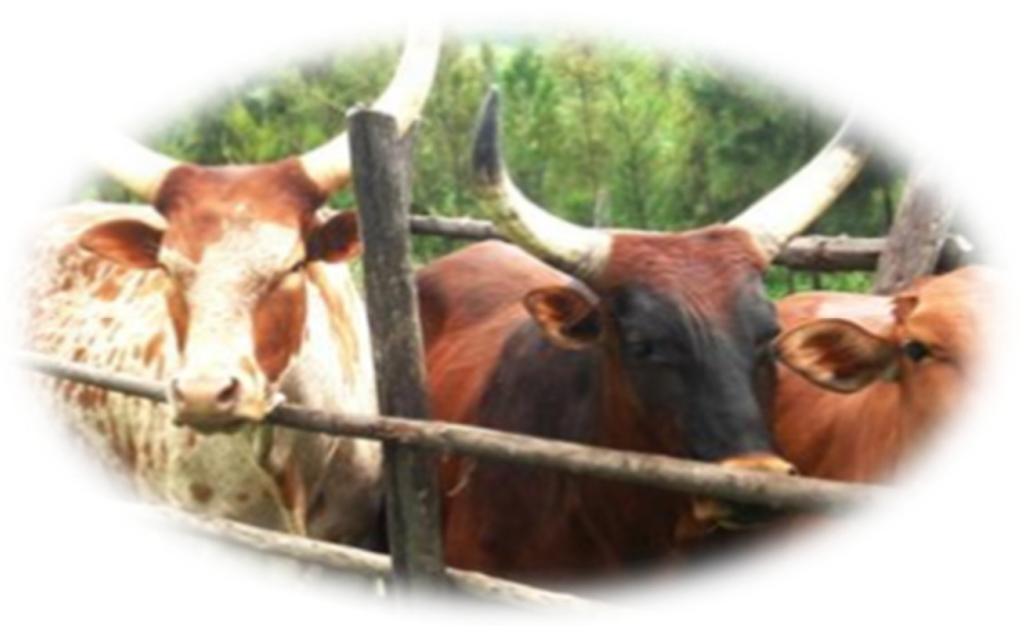

Figure 3: Stabulation cattle farming model

Source: convent of Jesuites priests of Cyangugu/Rwanda

The conservation has been envisaged here in the framework of the use of domestic biogas digester, which seems well appropriated for the resident around the Park and the small farmers in general. In this case, it is perceived in the frame of individual use of a digester, or commune use for serving around 10 households which lives together or near by the digester installation. The domestic Biogas digester conception is different from industrial biogas digester or that which can serve a community or much people at once. The biogas technology can play an important role in decreasing appreciably the numeral of the use of charcoal and firewood in the vicinity of that national Park. It contributes to the amelioration of the quality of life of those rural households. The importance of the usage of biogas technology will be for the cooking and the lighting, the waste management, the fertilizer, the stimulation of the agriculture and cattle farming. Let's Signal that the number of the Park resident is not known till now because of his size and because it touches 3 provinces of DRCongo such as Maniema, SouthKivu and North-Kivu.

\section{The Methanisation Principle}

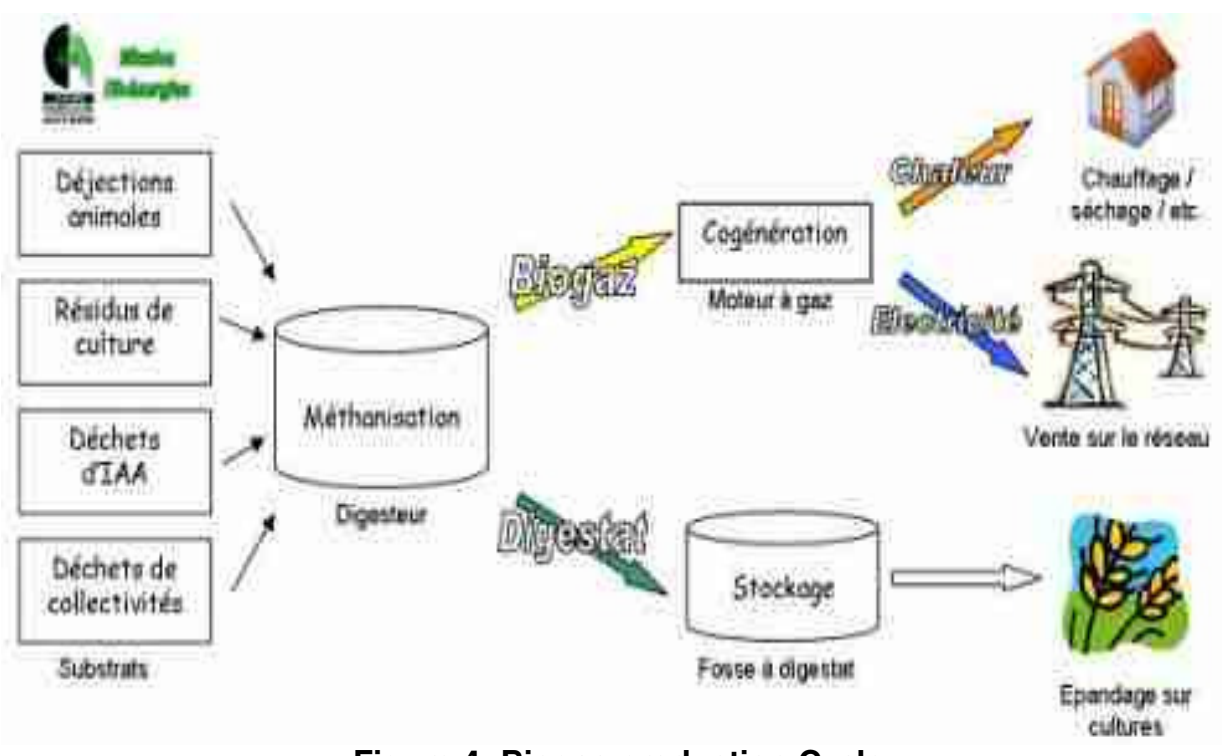

Figure 4: Biogas production Cycle

Source: www. Haute-marne.chambagri.fr 


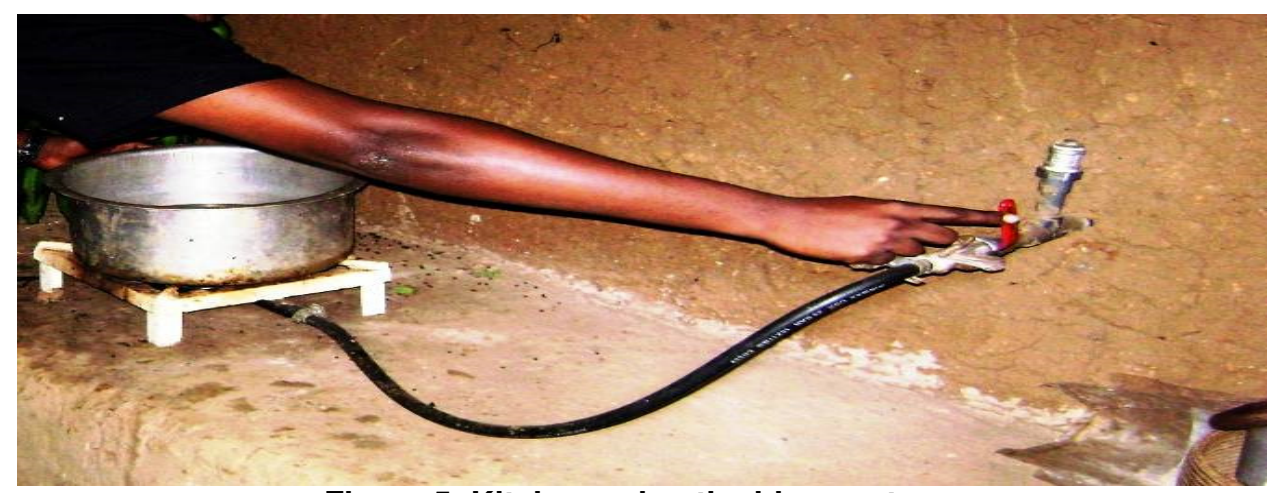

Figure.5: Kitchen using the biogas stove

Source: Luzira/Kalehe

\section{DISCUSSION}

By converting cow manure into methane biogas via anaerobic digestion the million of cattle in the USA would be able to produce 100billion kilowatts hours of electricity, enough to power millions of homes across the USA. In fact one cow can produce enough manure in one day to generate 3kilowatt hours of electricity; only 2.4 kilowatt hours of electricity are needed to power a single 100-watt light bulb for one day (State energy conservation Office, 2009). Furthermore, by converting cattle manure into methane biogas instead of letting it decompose, global warming gases could reduce 99 million metric tons or 4\% (Webber et al., 2008). Biogas in Germany is primarily extracted by the cofermentation of energy crops mixed with manure. The main crop used is corn. Organic waste, industrial and agricultural residues such as waste from the food industry are also used for biogas generation (Wieland, 2011). The rural population of the tropical countries has always had insufficient access to electricity or to a necessary driving force for the development of their activities. A great proportion of energy which they use, namely firewood, being destined to domestics' usages and particularly to cooking of food. From now, the combustibles from the biomass such as firewood and charcoal of wood represent till now $90 \%$ of households energetic need in sub-Saharan African zone, $70 \%$ in rural chine and between 30 and $90 \%$ of those needs in latine America (www.x-environnement).

In Ethiopia, Araya Asfaw, the regional director of the center of the Africa horn for environment has finalized a system witch fights against the deforestation in using the biogas backpack. To provide themselves with traditional energies (butane, petrol...) is not accessible to any coin purses. However, the firewood is dangerously destroying the environnement. In the actual rhythm of the deforestation, the forest could disappear totally from that zone. It's in that optic that Araya Asfaw made a partnership with Hohenheim University in Germany, for the Biogas Backpack. It's a tool which has got valve and allows the rurals to transport the Biogas from a big methaniser or big digester serving the whole community to their households. This green energy supplies then their stove with biogas or a gas stove. In practice, that filled backpack weighs $4.4 \mathrm{~kg}$ for a maximal volume of $1.2 \mathrm{~m}^{3}$. The central digester being supplied by the plant waste and manure paid from small farmers (www.courantpositif.fr).

Likewise for us, we are based on the fight against the deforestation around the National Park Kahuzi Biega in East of DRcongo. That's why we decided to use the manure produced by the farmers who dwell in the vicinity of the Park by installing little domestic digesters of $4 \mathrm{~m} 3$ of volume, which can be accessible to the most part of villages' farmers.

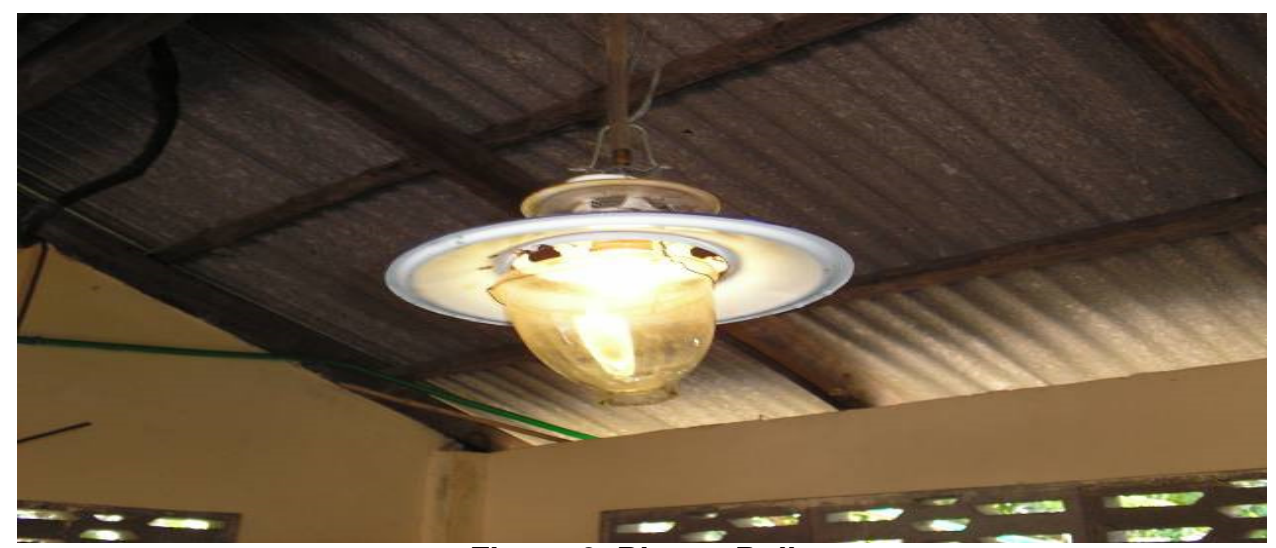

Figure 6: Biogas Bulb

Source: luzira/kalehe-DRCongo. 
Our study focused on the minimum numeral of 1000 domestic digesters where we can attend a result as followed in the proportion of $90 \%$ of firewood and $8 \%$ of charcoal which can be given back to the park each day. $19.800 \mathrm{~kg}$ or 19,8 tons of firewood replaced by $3.600 \mathrm{~m}^{3}$ of biogas per day, because $1 \mathrm{~m}^{3}$ of biogas replaces around $5.5 \mathrm{~kg}$ of firewood; $512 \mathrm{~kg}$ or 0,5 tons of charcoal replaced by $320 \mathrm{~m}^{3}$ of biogas per day, because $1 \mathrm{~m}^{3}$ of biogas replaces around $1.6 \mathrm{~kg}$ of charcoal.

According to the Bourkina-Faso domestic biogas national program $1 \mathrm{~m}^{3}$ of biogas replaces around $5.5 \mathrm{~kg}$ of firewood and $1 \mathrm{~m}^{3}$ of biogas replace around $1.6 \mathrm{~kg}$ of charcoal (NPB-BF, 2005). We notice that 19,8 $+0,5=$ 20,3 tons of firewood and charcoal put together to give back to the nature per day. In dividing the total of 20,3 tons by 3,36 tons we have 6 . Numeral which shows that the installation of 1000 digesters of $4 \mathrm{~m}^{3}$ can spare the vegetal heritage of the Park which has been destroyed for 6 years by one household in the area.

20.3 tons/24hours gives the numeral of tons replaced by the use of biogas per hour, it is 0.9 ton per hour after the installation of those domestic biodigesters.

After getting the gas, the residues of organic materials constitute a real fertilizer for the fields of the resident of KBNP. That digestat once poured on the cultures, the yield is satisfactory (Chaslerie, 2002). The use of the technology of Biogas enters in the processes of the production of biogas for the development (Uri, 1994).

\section{CONCLUSION}

The people surrounding the park are quoted as the main actors in their purpose of looking for wood and embers first for the kitchen and for the sale after; then the principle to which the direct people near the park must live by in their direct environment must be considered.

With the aim of advising and sensitizing the population near the park to fight against the deforestation, many actions must be undertaken mainly in the supply of the biodigesters to the farmers who are found in the area especially those who have more than two cows, in encouraging them to use the cattle farming of cowshed, in growing up fodder plants in their fields, in using biogas in the kitchen instead of woods and embers, in using the fertilizer coming from the digester in their fields, and in following all the instructions required for the maintenance of a digester. Therefore, one installed digester of $4 \mathrm{~m}^{3}$ in a household saves $20 \mathrm{~kg}$ of embers and wood per day, and more than 20.3 tons by installing 1.000 digesters in the area.

The results from our inquiries indicate that: The daily need for one medium household in firewood and charcoal together is $10 \mathrm{Kg}$. This means that each household uses $3.360 \mathrm{~kg}$ or 3.36 tones of firewood and charcoal per year.

This technology which uses gas stove instead of fire from firewood and charcoal of wood stays a solution well appropriated for the surrounding KBNP population. In that optic, a satisfied result is expected where wood and charcoal from the Park will be seriously avoided, being replaced by the use of Biogas stove and biogas bulb. This manner of enhanced value of organic wastes for the small farmers of the country or village shall bring them many advantages such as the fight against deforestation, the promotion of cattle farming of cows and other domestic animals, to enhance the value of digestat in using as free fertilizer in the fields. It's true that the deforestation is going on in the tropical zone and without palliatives technics in energy sector such as biogas in the conservation of the world heritage, the forest can disappear in the future in this zone.

\section{REFERENCES}

Berger S., Couturier C., (2008), La méthanisation en milieu rural, Tec\&Doc, Lavoisier, Paris.

Bertrand De La Farge, (1995), Le biogaz. Procédés de fermentation méthanique, éd. Masson, Paris.

Champiat D. et al. (1994), Biologie des eaux: Méthodes\& techniques, Masson.

Chaslerie T., (2002), Techniques de bioconversions : la biométhane, IUT Génie thermique et énergie, Paris.

Burdekin, D., (2003) An investigation into the continuous monitoring of landfill gas and the commercial viability of intelysis landfill gas monitor, Manchester University, unpublished thesis.

State energy conservation office (Texas) (2009). "Biomass energy: Manure for fuel", Texas, p.4

Uri M., 1994: Les procédés de production de biogaz pour le développement de ressources, Sophie Lacoste, Jérusalem, 233p.

Annexe 1 de la Brochure concernant le système international d'unités, 1997, p. 60

Programme national de Biogaz du Burkina-Faso (NPB-BF) (2005), manuel de formation pour les constructeurs des biodigesteurs domestiques, pp.14-17.

National Non-Food Crops Centre "NNFCC Renewable fuels and Energy Factsheet Anaerobic Digestion", 2011.

Claverton Energy Conference. "Biomethane fueled vehicles the carbon neutral option, 24 October 2009, Bath, Uk.

Fischer (1995), Rolf peter sierferle: Technik als küstung des revolutinären volkes: Hans Freyer, in ders: Die conservative Revolution. Fünt biographische skizzen. Frankfurt am Main, allemagne.

Mugaruka E., Conservation du PNKB à travers l'utilisation du Biogaz pour les populations riveraines, mémoire inédit Unic-Bukavu, 2011-2012. 
UNESCO, Parc national de Kahuzi-Biega consulté le 28 mai 2010, 21 ${ }^{\text {St }}$ session 1997.

http://fr.wikipedia.org

www.clarke-energy.com/../biogas

www.haute-marne.chambagri.fr/kit/environnement-energie/energie-et-agroressources/methanisation-a-la-

ferme.html

www.electrigaz.com/faq fr.htm

Cite this Article: Chanceline BM, Etienne MM, Godefroid KM, Soleil HS, 2014. Conservation Strategy of Kahuzi-Biega National Park by the use of Biogas among the Surrounding Population: Greener Journal of Environmental Management and Public Safety, 3 (2): 035- 042. 